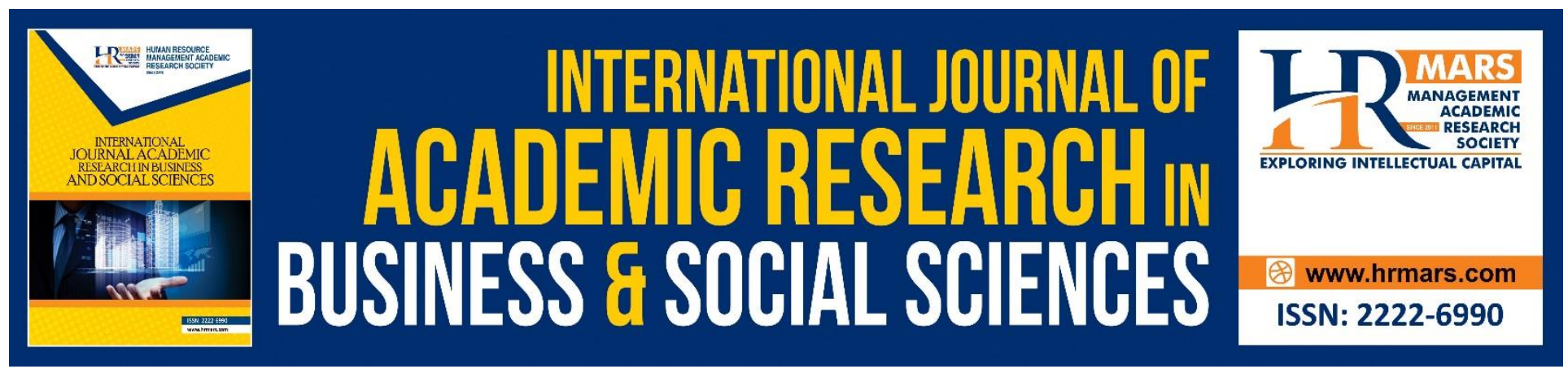

\title{
Social Networks in The Development of Rural Malay Herbal Entrepreneurship in Malaysia
}

\author{
Kamal Chandra Paul and Ismi Arif Ismail
}

To Link this Article: http://dx.doi.org/10.6007/IJARBSS/v10-i16/8426

DOI:10.6007/IJARBSS/v10-i16/8426

Received: 10 October 2020, Revised: 02 November 2020, Accepted: 29 November 2020

Published Online: 15 December 2020

In-Text Citation: (Paul \& Ismail, 2020)

To Cite this Article: Paul, K. C., \& Ismail, I. A. (2020). Social Networks in The Development of Rural Malay Herbal Entrepreneurship in Malaysia. International Journal of Academic Research in Business and Social Sciences, 10(16), 381-391.

\section{Copyright: (c) 2020 The Author(s)}

Published by Human Resource Management Academic Research Society (www.hrmars.com)

This article is published under the Creative Commons Attribution (CC BY 4.0) license. Anyone may reproduce, distribute, translate and create derivative works of this article (for both commercial and non-commercial purposes), subject to full attribution to the original publication and authors. The full terms of this license may be seen at: $\underline{\text { http://creativecommons.org/licences/by/4.0/legalcode }}$

Special Issue: Youth and Community Wellbeing: Issues, Challenges and Opportunities for Empowerment V2, 2020, Pg. 381 - 391 http://hrmars.com/index.php/pages/detail/IJARBSS JOURNAL HOMEPAGE

Full Terms \& Conditions of access and use can be found at http://hrmars.com/index.php/pages/detail/publication-ethics 


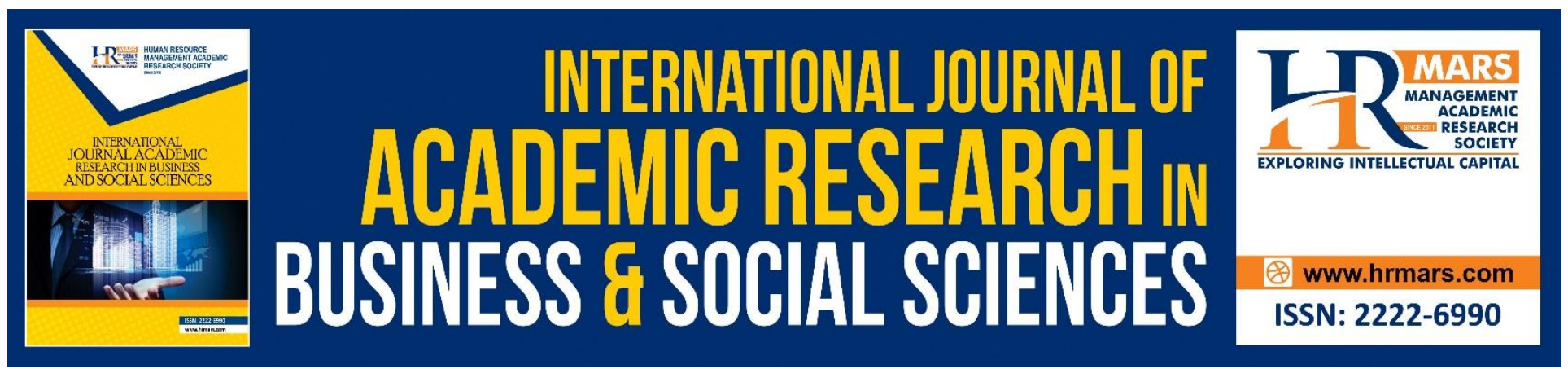

\title{
Social Networks in The Development of Rural Malay Herbal Entrepreneurship in Malaysia
}

\author{
${ }^{1}$ Kamal Chandra Paul and ${ }^{1,2}$ Ismi Arif Ismail
}

${ }^{1}$ Institute for Social Science Studies, Putra Infoport, Universiti Putra Malaysia, 43400, UPM Serdang, Selangor, Malaysia, ${ }^{2}$ Faculty of Educational Studies, Universiti Putra Malaysia, 43400, UPM Serdang, Selangor, Malaysia

Email: pharmacistpaul@gmail.com

\begin{abstract}
Previous studies found that networking is the key point for the entrepreneurship development. It has been long believed that social networks always influence entrepreneurship growth. The aim of this study is to investigate how rural Malay family-based herbal entrepreneurs are using social networking to develop their herbal entrepreneurship. It is a phenomenological qualitative research with eight rural Malay herbal entrepreneurs in Peninsular Malaysia namely Kelantan, Kedah, Pahang, Perlis and Terengganu. A purposive sampling approach was used to select the entrepreneurs residing in the rural areas and the selection criteria in the study also included those who have run their business with family members for at least the past four years with a minimum of three products. The findings of this study showed that the five states' rural Malay herbal entrepreneurs are using social network among own community peoples, not like other states entrepreneurs'. As a result, herbal entrepreneurship is not developing owning to lack of social network with other state entrepreneurs and customers, suppliers, as well as financial constraints, technical knowledge. Finally, based on the findings of this study, the entrepreneurs need consistent trainings from the government and other related government link companies on how to develop social network with others and the importance of social network for their entrepreneurship development.
\end{abstract}

Keywords: Social Network, Herbal Entrepreneurs, and Entrepreneurship

\section{Introduction}

The use of social network concepts in social science has enhanced interest in the last couple of years. In this paper, social networks involve the social contexts of business (Granovetter, 1985; Burt, 1992). Social network means to create linkage between entrepreneurs and others such as people, organization and that interaction provide the resources which are important in establishing a business as well as to sustain a new firm (Johannisson, 1988: Larson, 1991; Hansen, 1995). Most of the developing countries like India, China, Thailand and others use social network for their herbal entrepreneurship development. Networking is helpful for any entrepreneurship specifically to get 
bank loan, increase sales volume, finding new customers, agents, and suppliers.

Most of the countries in the world use social networking for any type of entrepreneurship development and for it they implement policies and programs to practice social network (Fafchamps, 1997, 2001, 2004; Barr, 2000; Jack, 2005; Katungi et al., 2007; Nowinski \& Rialp, 2015; Bosma et. al, 2012; De Jong, 2013). Tata and Prasad (2008) mentioned that development or failure of small enterprises depend on social networks that provide all resources.

Entrepreneurship in rural areas has been considered as a critical area to contribute country's quality of life, economic growth, and job creation (Van Prag and Versloot, 2007; McMullen et al., 2008; Audretsch, 2007; Shu, 2001; Brewer \& Gibson, 2014). As a result, many countries have been using it as a model for their countries' development and economic growth. Like Korea, Japan, India, Malaysia, Germany and other countries that changed their countries' economy through rural entrepreneurship. Earlier, different scholars, academicians and researchers believed that only urban large-scale entrepreneurs can contribute to the country's growth. The government of Malaysia is allocating more budget annually mainly for rural Malay entrepreneurship development such as stationery shop, agricultural, herbal and other technology-based entrepreneurship. For instance, even in the Tenth Malaysia Plan (2011-2015), the government is still concerned about the development of Malay and as such a lot of schemes were taken and assistance has been created to increase the participation of Malays into entrepreneurship.

In 1970, the government of Malaysia implemented the New Economic Policy (NEP) for the Malays and offered them to join technology-based entrepreneurship instead of general Small Medium Enterprises (SMEs). As per previous research data showed general entrepreneurship is growing rapidly but technology-based entrepreneurships in the field of Herbal, Bio-technology, Food Technology etc are still now is in its nascent stage (Hawa, 2011) owning to lack of technical knowledge, know-how, social network, financial support and operational knowledge (Ismail and Sulaiman, 2007; Paul et al., 2014; Jamai, 2006; Nordin et al., 2008; Ellitan, 2002). Malaysia is a multi-ethnic country with Malays (Bumiputra), Chinese, Indian and other groups living together with harmony in the same country. Each ethnic group has its own culture and social background as in the business they practice this. In Malaysia, Chinese ethnic group is very strong in network development compared to Malays in the entrepreneurship sector.

According to Hamidon (2009), the general category entrepreneurship is developing among Malay communities every year, but technology- related entrepreneurship is very low compared to other ethnic groups like the Chinese. It is worth to mention that this present study of herbal entrepreneurship is a form of technological entrepreneurship. According to Murray (2011), the herbal entrepreneurship in Malaysia has become another economic growth engine and it has the future to become a significant sector (Ibrahim, 2006; Jamai, 2006). The estimated market value of herbal industry is RM7.97 billion (Kasim, 2007) and also different researchers in this field mentioned that in a short period it would be RM10 billion. In 2003, total GMP licenses numbered 94 and it has now increased to 170 (Ministry of Health, 2013, Malaysia). As a result, the number of GMP licenses for herbal product development is tremendously increasing globally. In Malaysia now, all government 
INTERNATIONAL JOURNAL OF ACADEMIC RESEARCH IN BUSINESS AND SOCIAL SCIENCES

Vol. 10, No. 16, Youth and Community Wellbeing: Issues, Challenges and Opportunities for Empowerment V2. 2020, E-ISSN: 2222-6990 @) 2020 HRMARS

hospital doctors are prescribing herbal GMP grade products as an alternative medicine. From the above report, it is evident that use of herbal products and number of entrepreneurs are tremendously increasing every year in Malaysia.

The government of Malaysia is also increasing fund allocation, training, promotional and human resource activities based on entrepreneurship need every year especially in herbal entrepreneurship development. However, the Malays' involvement in herbal sector is very low (Ling et. al., 2009). It is evident that not many studies have been conducted on herbal and entrepreneurship development (Paul et. al., 2013; Ucbasaran et al., 2001; Smith et. al., 2009; Kirzner, 1973). At the end of the day, the government of Malaysia has found that general category entrepreneurship is growing smoothly but highly populated Malay states like Kedah, Pahang, Perlis, Kelantan and Trengganu are at an infancy stage and conducted lot of research on entrepreneurship but not herbal entrepreneurship development using social network (Paul et al., 2013). This study is to investigate how rural Malay herbal entrepreneurs use social network for their entrepreneurship development.

\section{The Importance of Networking for Entrepreneurship in Malaysia}

The entrepreneurship development and its sustainability depends on various factors in the market and it varies from country to country. However, entrepreneurial network has been identified as one of the areas that should be looked into attention mainly nascent and existing entrepreneurs among different category SMEs (Paul et al., 2013). Other research scholars, academicians in entrepreneurship and business fields have mentioned in their studies that social network is important to develop local and overseas market (Zizah et al., 2007). Entrepreneurs will be able to access to various support provided by the government such as Ministry of International Trade Industry (MITI), Malaysian Industry Development Authority (MIDA), Malaysia External Trade Development Corporation (MATRADE), Small Medium Industry Development Corporation (SMIDEC), Malaysian Technology Development Corporation (MTDC), and other agencies, in order to enter into international market. Social network positively associates with business performance in Malaysia (Surin, et al., 2015). However, currently the Industrial Linkage Program (ILP) under SMIDEC recognized "networking" as the main focusing area for entrepreneurship development to compete locally or internationally (Zizah et al., 2007).

\section{Chinese and Malay Business Networking}

Many research scholars and academicians claim that Chinese business networking is stronger with customers, suppliers, employers, government and government linked agencies and other related parties, as a result they are successful in this sector (Kotkin, 1993; Hamilton, 1996). They also believe network plays an important role in development of entrepreneurship (Ann, 2006; Gomez, 1999, Tehseen et al (2018). On the other hand, other research scholars also supported the above argument that Chinese network is really stronger than other ethnic group like Malay, so they should follow Chinese network entrepreneurial culture to become a successful entrepreneur (Sally Cheong, 1996). The importance of networking is not only limited to Chinese but extended to Malay and other ethnic group entrepreneurs. Although some have network but they did not utilize it. Utilization of networking is very less among other ethnic like Indian compare Chinese (Tehseen et al., 2018). Chinese are good in general business networking but Malays are more capable in government agency 
INTERNATIONAL JOURNAL OF ACADEMIC RESEARCH IN BUSINESS AND SOCIAL SCIENCES

Vol. 10, No. 16, Youth and Community Wellbeing: Issues, Challenges and Opportunities for Empowerment V2. 2020, E-ISSN: 2222-6990 @) 2020 HRMARS

related activities and business (Faridah, 2001; Gomez, 1999; Gomez et al., 2004; Hashim, 2007; Ibrahim et al., 1988).

\section{Entrepreneurial Competencies, Social Network and Entrepreneurship Success}

Entrepreneurial competencies always influence the entrepreneurship success (Man et al., 2002; Ahmad et al., 2010). The competencies also influence to form network, business performance and success (Sarwoko et al., 2013). On the other hand, networking in entrepreneurship success is widely accepted by different research scholars' findings (Klyver and Foley, 2012; Batjargal, 2010; Hoang and Antoncic, 2003; Jack, 2010; Zhao et al., 2010). Scholar commented that social network is essential for both stage of starting and success of entrepreneurship (Subrahmanyam, 2019). Therefore, social networks can be divided into four categories namely mentors, professional fora, business and personal networks. Mentors refer to more formal relationship with customers, suppliers, competitors; professional fora are the forms of the information sharing through joining conferences, seminars and workshop related to entrepreneurship or business; business network links to the employees; personal network means the relationship with relatives, friends, colleagues and others which build up strong relationship for entrepreneurship success (Fernandez-Perez et al., 2015).

\section{Methods}

This study is qualitative in nature that relies on phenomenology approach. The purpose of the qualitative phenomenology research study was to investigate the individual's personal experience of rural Malay family-based herbal entrepreneurship development using social network. The researcher selected eight rural Malay herbal entrepreneurs with minimum of four years entrepreneurial experiences having minimum three products from the five states of Peninsular Malaysia namely Kelantan, Kedah, Pahang, Perlis and Terengganu (Reference Table: 1). Family members are involved to operate from rural areas where they are residing. Entrepreneurs are running this entrepreneurship with their family members. Data were gathered via in-depth semi-structured individual face to face interview and the interview time for each participant was an hour or more as long as researcher decided data is saturated.

\section{Results}

\section{Profile of Respondents}

As stated earlier, the findings of this study were obtained from eight rural Malay family-based herbal entrepreneurs from five states of Malaysia. Table 1 shows the profile of the rural Malay familybased herbal entrepreneurs: 
INTERNATIONAL JOURNAL OF ACADEMIC RESEARCH IN BUSINESS AND SOCIAL SCIENCES

Vol. 10, No. 16, Youth and Community Wellbeing: Issues, Challenges and Opportunities for Empowerment V2. 2020, E-ISSN: 2222-6990 @ 2020 HRMARS

Table I: Profile of rural Malay family-based herbal entrepreneurship in Malaysia

\begin{tabular}{|c|l|l|l|l|l|l|l|}
\hline $\begin{array}{l}\text { No of } \\
\text { respondents (R) }\end{array}$ & State & $\begin{array}{l}\text { Educational } \\
\text { status }\end{array}$ & Gender & $\begin{array}{l}\text { Entrepreneurship } \\
\text { started year }\end{array}$ & $\begin{array}{l}\text { Monthly } \\
\text { sales(RM) }\end{array}$ & $\begin{array}{l}\text { No } \\
\text { Employees }\end{array}$ & $\begin{array}{l}\text { Support } \\
\text { agency }\end{array}$ \\
\hline 1 & Kelantan & Basic & Female & 1999 & $80 \mathrm{~K}$ & 5 & MARA \\
\hline 2 & Kelantan & Basic & Male & 1997 & $68 \mathrm{~K}$ & 4 & MARA \\
\hline 3 & Kedah & STPM & Male & 1998 & $60 \mathrm{~K}$ & 3 & MARA \\
\hline 4 & Kedah & Basic & Male & 1996 & $57 \mathrm{~K}$ & 5 & MARA \\
\hline 5 & Pahang & SPM & Male & 1997 & $63 \mathrm{~K}$ & 4 & OWN \\
\hline 6 & Pahang & Graduate & Male & 1990 & $75 \mathrm{~K}$ & 5 & MARA \\
\hline 7 & Perlis & Basic & Male & 1996 & $50 \mathrm{~K}$ & 2 & OWN \\
\hline 8 & Trengganu & SPM & Male & 1998 & $74 \mathrm{~K}$ & 5 & OWN \\
\hline
\end{tabular}

As can be seen in Table 1, eight rural Malay herbal entrepreneurs as R1, R2, R3, R4, R5, R6, R7 and R8 from the five states namely Kelantan, Kedah, Pahang, Perlis, Terengganu and among them only one is female entrepreneur from Kelantan (R1). It was also identified that these entrepreneurs have started their business since the 90's. In general, rural herbal entrepreneurs R1, R2, R3, R4, R6 got financial support from the MARA agency at the commencement of herbal entrepreneurship and R5, R7, R8 did not get any financial support from any government agency rather they started with their own finance. Moreover, R1, R2, R4, R7 have basic education and on the other hand, R5, R8 got SPM, R3 are STPM education certificate holders and R6 is a degree holder. The main theme of the study was to explore the perspective of social network among rural Malay herbal entrepreneurs that means how they use or manage social network.

\section{Social Network within own Community}

The study found that social network is limited within the entrepreneurs own community. For instance, according to R1 (Kelantan) "I maintain my business relation among Kelantanese people only, even my raw materials supplier and customers are also under Kelantan" and R2 (Kelantan) said "most of my social network advancements are through religious groups and community gathering areas."

Besides, R7 (Perlis) and R8 (Trengganu) confined their social network within their own community too. For instance, R7 (Perlis) said that "mostly I spent more time for the company I worked and for this reason I had less time to develop social contacts and maintain formal relations with supplier and customers who are from my own community". Entrepreneur R4 added that "I maintain my personal network with my relatives, friends and community but trust is very important to maintain a good relationship. Lots of people say they have good relationship but in most of the cases they are not trustworthy. As a result, they avoid sharing their business-related activities."

\section{Social Network with other Ethnic Groups and States}

Here R3 and R4 (Kedah), R5 and R6 (Pahang) used social network for their entrepreneurship development. They used network not only with own community and states but also with other states, other ethnic communities, customers and suppliers. According to R3, "social relations is very important. After my father died and I took responsibility, my network sales area spread out to other states too". He added "although I don't have technical knowledge and other government's new herbal 
INTERNATIONAL JOURNAL OF ACADEMIC RESEARCH IN BUSINESS AND SOCIAL SCIENCES

Vol. 10, No. 16, Youth and Community Wellbeing: Issues, Challenges and Opportunities for Empowerment V2. 2020, E-ISSN: 2222-6990 @) 2020 HRMARS

development policy, but I am surviving on my social networking with other ethnic groups and states". The study found that R6 (Pahang) have sales agents from all ethnic's groups, including Chinese, Indians and others. When asked about his social network, he (R6) said, "cultural mindset interruption in social network which I have overcome this in thinking and spread my network over all the ethnic groups. In addition, I attend rarely information sharing link workshops and always try keeping up relations with government institutes, friends and relatives which may support in my entrepreneurship". Notwithstanding, R4 said "we are planning to develop our social network with other states" and it is mentioned earlier this entrepreneur didn't have any network with other ethnic groups and other states. Moreover, the findings also showed that only R8 and R5 use their social network through Facebook, but this network is limited to own ethnic group only.

\section{Personal Network with Government, Banks and Government-Link- Companies (GLC)}

The study showed some entrepreneurs are good in personal network with Government, Bank and Government-Link-Companies (GLC) for their entrepreneurship development as mentioned by R2 who said "we only have strong relationship with government agency". Besides R5, R6 and R8 mentioned "Our products are selling through government support, marketing and social media too".

\section{Discussions and Conclusions}

Empirical findings from the eight rural Malay herbal entrepreneurs in the five states of Peninsular Malaysia, namely Kelantan, Kedah, Pahang, Perlis and Terengganu and among them all of Malay herbal entrepreneurs are using community- oriented social network for their entrepreneurship. However, the entrepreneur used social network not only for own community but also among all other ethnic groups and spread out to other states too. Here all entrepreneurs are Malays and engaged with herbal entrepreneurship in rural areas. So community is a big support for the all entrepreneurs. In addition, some entrepreneurs are weak in social networking and they are doing business with own community people. As a result, their sales volumes are not increasing as they plan to achieve, social networking is important to develop local and overseas market (Zizah et al., 2007). So, they are not developed relatively with other state entrepreneurs.

From the view point of informants and the observation by the researcher, most of the Malay herbal entrepreneurs' social network such as personal network is shaky due to untrustworthiness. It means their relationship is poor. According to the entrepreneurs, the social network tie- up among own community people is not interdependent. That is the lack of trustworthiness, so they can't share their knowledge of doing business.

In addition, most of them use limited social network, for instance it is limited within their own community and own religion. Moreover, some entrepreneurs strongly chose to work with own community only due to cultural mindset, their reluctance to expand herbal entrepreneurship with other ethnic groups. Not only that, Malay herbal entrepreneurs strongly dislike working outside of their current state. Above all, it is concluded and found that all Malay herbal entrepreneurs use their personal network among own community, that's why they can easily make link with government agencies and banks. Malays are more capable to link to government agency (Faridah, 2001; Gomez et al., 2004; Hashim, 2007). 
Finally, all entrepreneurs are own community culture- oriented, as they are not cooperated with anything in terms of business development with each other. This study showed the Malay herbal entrepreneurs use social network in their herbal entrepreneurship and it is true that the productive information and resources can be achieved through social network.

Based on the results of this study, several recommendations are put forward for the Government of Malaysia:

(1) inform Malay herbal entrepreneurs to follow other ethnic groups on how they are using social network for their herbal entrepreneurship development

(2) training on social network importance for Malay herbal entrepreneurship and change their mind- set

(3) Malay herbal entrepreneurship should be available in using the network in all states for their benefit instead of focusing on their community

(4) organize training programs based on the needs of Malay herbal entrepreneurship.

If these steps are taken immediately by the government then slowly Malay herbal entrepreneurs will change their mind- set to use social network and in the future rural Malay herbal entrepreneurs will be able to face all challenges both locally and globally like other ethnic groups in Malaysia.

\section{Acknowledgement}

The research was funded by Research University Grant Scheme (RUGS), Universiti Putra Malaysia under the title of "Rural Malay Herbal Entrepreneurship Development in Malaysia".

\section{References}

Ahmad, N. H., Halim, H. A., and Zainal, S. R. M. (2010). Is Entrepreneurial Competency the Silver Bullet for SME Success in a Developing Nation, International Business Management, 4(2), 67-75.

Ann, W. S. (2006). The Business Secret of Chinese people (Rahsia bisnes orang China). Kuala Lumpur: PTS Professional Publishing Sdn. Bhd.

Audretsch, D. B. (2007). Entrepreneurship capital and economic growth. Oxford Rev. Econ Policy, 23 : 63-78.

Barr, A. (2000). Social capital and technical information flows in the Ghanaian manufacturing sector, Oxford Economic Papers, 52(3): 539-559.

Batjargal, B. (2010). Network dynamics and new ventures in China: A Longitudinal study. Entrepreneurship \& Regional Development, 22(2): 139-53.

Bosma, N., Hessels, J., Schutjens, V., Van Praag, M., and Verheul, I. (2012). Entrepreneurship and Role Models, Journal of Economic Psychology 33(2), 410-424.

Brewer, J., and Gibson, S. W. (2014). Necessity entrepreneurs: Microenterprise education and economic development (pp. 160-182). Cheltenham, UK: Edward Elgar Publishing Ltd.

Burt, R. S. (1992). Structural Holes: The Social Structure of Competition. Harvard University Press: Cambridge, Massachusetts, and London, England. 
INTERNATIONAL JOURNAL OF ACADEMIC RESEARCH IN BUSINESS AND SOCIAL SCIENCES

Vol. 10, No. 16, Youth and Community Wellbeing: Issues, Challenges and Opportunities for Empowerment V2. 2020, E-ISSN: 2222-6990 @) 2020 HRMARS

De Jong, J. P. J. (2013). The Decision to Exploit Opportunities for Innovation: A study of High-Tech Small-Business Owners, Entrepreneurship: Theory and Practice, 37(2): 281-301.

Ellitan, L. (2002). Factors influencing the success of technology adoption: A case study of Indonesian manufacturing firms. Master's thesis, Universitas Kristen Petra, Surabaya, Indonesia.

Fafchamps, M. (2001). Networks, communities and markets in Sub-Saharan Africa: implication for firm growth and investment. Journal of African Economics 10: 109-142.

Fafchamps, M. (2004). Market institutions in Sub-Sharan Africa, Theory and evidence, London: MIT Press.

Fafchamps, M. (1997). Trade credit in Zimbabwean manufacturing. World Development, 25(5): 795815.

Faridah, S. (2001). Bumiputra Commercial and Industrial Community in the Food-Processing Industry: An Analysis of Institutional Support. Humanomics, 17(1):86-98.

Gomez, E. T. (1999). Chinese Business in Malaysia: Accumulation, Accommodation and Ascendance. Richmond: Curzon Press.

Gomez, E. T., Loh, W. L., and Lee, K. H. (2004). Malaysia. In Gomez, E. T. \& Michael Hsiao, H. H. (Ed), Chinese Business in Southeast Asia (62-84). London and New York: Routledge Curzon.

Granovetter, M. (1985). Economic action and social structure: A theory of Embeddedness. American Journal of Sociology, 91(3): 481-510.

Hamidon, S. (2009). Development of Malay Entrepreneurship in Malaysia. PhD thesis, Massey University, Auckland, New Zealand.

Hamilton, G. G. (1996). Asian Business Network. Berlin: Walter de Gruyter.

Hansen, E. L. (1995). Entrepreneurial network and new organization growth, Entrepreneurship: Theory \& Practice, 19(4): 7-19.

Hashim, M. K. (2007). SMEs in Malaysia: A Brief Handbook. Petaling Jaya: August Publishing.

Hawa, Z. J. (2011). Growing Our Herbal Industry. Retrieved from http://pmr.penernagan.gov.my/index.php/sosial/11684

Hoang, H., and Antoncic, B. (2003). Network-based research in entrepreneurship- A critical review. Journal of Business Venturing, 18(2): 165-87.

Ibrahim, J. (2006). The scientific values of Malaysian herbal products, Malaysian Journal of Health Sciences, 4(1): 59-70.

Ismail, R., \& Sulaiman, N. (2007). Technical efficiency in Malay manufacturing firms, International journal Business Society, 8(2): 24-37.

Jack, S. L. (2005). The role, use and activation of strong and weak network ties: a qualitative analysis, Journal of Management Studies, 42(6): 1233-1259.

Jack, S. L. (2010). Approaches to studying networks: Implications and outcomes, Journal of Business Venturing 25(1): 120-37.

Jamai, A. J. (2006). Malay traditional medicine: An overview of scientific and technological progress, Special Feature: Traditional Medicine: S \&T Advancement, Tech Monitor. Nov-Dec 2006: 3749.

Johannisson, B. (1988). Business formation: A network approach. Scandinavian Journal of Management, 4(3-4): 83-99.

Kasim, A. Z. A. (2007). Herbal biotechnology development: The way forward \& market access opportunities. Paper presented at EUM-BIO Business Partnering Seminar, MATRADE 
INTERNATIONAL JOURNAL OF ACADEMIC RESEARCH IN BUSINESS AND SOCIAL SCIENCES

Vol. 10, No. 16, Youth and Community Wellbeing: Issues, Challenges and Opportunities for Empowerment V2. 2020, E-ISSN: 2222-6990 @) 2020 HRMARS

Exhibition and Conference Centre, Malaysia 25 October.

Katungi, E., Machethe, C., and Smale, M. (2007). Determinants of social capital formation in rural Uganda: implication for group-based agricultural extension approaches, African Journal of Agricultural and Resource Economics 1(2): 167-190.

Kirzner, I. M. (1973). Competition and entrepreneurship, University of Chicago Press Chicago Press, Chicago.

Klyver, K., and Foley, D. (2012). Networking and culture in entrepreneurship. Taylors \& Francis.

Kotkin, J. (1993). Tribes: How Race, Religion, and Identity Determine Success in the New Global Economy. New York: Random House.

Larson, A. (1991). Partner networks: Leveraging external ties to improve entrepreneurial performance. Journal of Business Venturing, 6(3): 173-188.

Ling, C. K., Selvadurai, S., and Hamid, B. A. (2009). Malay youth entrepreneurship in Malaysia: An empirical update. Malaysian Journal of Society and Space, 5: 2955-67.

Man, T. W., Lau, T., and Chan, K. F. (2002). The competitiveness of small and medium enterprises: A conceptualization with focus on entrepreneurial competencies, Journal of Business Venturing, 17(2): 123-142.

McMullen, J. S., Bagby, D. R., and Palich, L. E. (2008). Economic freedom and the motivation to engage in entrepreneurial action, Entrepreneurship Theory and Practice, 32: 875-895.

Ministry of Health. (2011), Malaysia National Pharmaceutical Control Bureau, Ministry of Health Malaysia.

Murray, H. (2011). Expanding the Malaysian herbal industry by developing the farmer-government University Nexus. Processing of the $7^{\text {th }}$ Malaysia Agro-Bio International Conference with the $12^{\text {th }}$ Malaysian International Food and Beverage Trade Fair, July 12-15,2011, Putra World Trade Centre, Kuala Lumpur, Malaysia.

Nowinski, W., and Rialp, A. (2015). The Impact of Social Networks on Perceptions of International Opportunities, Journal of Small Business Management.

Paul, K. C., Hamzah, A., Abu Samah, Ismail, A. I., and D'Silva, L. J. (2013). Development of Rural Herbal Entrepreneurship in Malaysia, International Journal of Business Management, 8(18): 95-100

Paul, K. C., Hamzah, Abu Samah, B., Ismail, A. I., and D'Silva, L. J. (2014). Rural Malay Involvement in Malaysian Herbal Entrepreneurship, Journal of Asian Social Science 10(2): 202-208

Paul, K. C., Abu Samah, Ismail, A. I., and D'Silva, L. J. (2013). Technology Implementation Barrier of Rural Malay Herbal Entrepreneurship in Malaysia, Journal of Applied Sciences, 14(1):72-76.

Cheong, S. (1996). Bumiputra entrepreneurs in the KLSE, Petaling Jaya: Corporate Research Service.

Sarwoko, E., Armanu, S., and Hadiwidjojo, D. (2013). Entrepreneurial Characteristics and Competency as Determinant of Business Performance in SMEs, IOSR Journal of Business and Management (IOSR-JBM), 7(3): 31-38.

Shu, X. (2001). Entrepreneurship and economic growth. Proceeding of the Sino-Australian Conference of innovation and Entrepreneurship, Policy and Practice, November 7-9, 2001, Hangzhou, China.

Smith, B. R., Matthews, C. H., and Schenkel, M. T. (2009). Differences in entrepreneurial opportunities: The role of tastiness and codification in opportunity identification. Journal of small business management, 47(1): 38-57.

Subrahmanyam, S. (2019). Social network for entrepreneurship, International Journal of Commerce 
and Management Research, Impact Factor: RJIF 5.22, 5(1): 117-122.

Surin, E. F., Wahab, I. Ab., Hussin, M. H. F., Saad, M. N., and Harun, M. H. M. (2015), Using the Social Network for Business Sustainability: Examining Start-up SME Firms in Malaysia. Information Management and Business Review, 7(5): 18-26.

Tata, J., and Prasad, S. (2008). Social capital, collaborative exchange and microenterprises performance: the role of gender. International Journal of Entrepreneurship and Small Business, 5(3/4): 375-385.

Tehseen, S., Qureshi, Z. H., and Ramayah, T. (2018). Impact of Network Competence on Firms Performances among Chinese and Indian Entrepreneurs: A Multigroup Analysis, Research Article: 2018. International Journal of Entrepreneurship, 22(2).

Ucbasaran, D., Westhead, P., and Wright, M. (2001). The focus of entrepreneurial research: Contextual and process issues. Entrepreneurship: Theory and Practice, 25(4): 57-80.

Van Praag, C., and Versloot, P. (2007). What is the value of entrepreneurship? A review of recent research, Small Business Econ., 29(4): 351-382.

Ibrahim, Y., Jamil, A. Z., and Hashim, R. (1988). Small and Medium Scale Enterprises in Malaysia: Bumiputera participation. In Mohayidin, M. G. and Abd Hamid, S. (Ed), Small and Medium Enterprise in Malaysia: Technological and managerial capability (pp. 43-48). Kuala Lumpur: Small Business Development Centre, Universiti Pertanian Malaysia (now known as Universiti Puta Malaysia).

Zhao, X., Frese, M., and Giardini, A. (2010). Business owners network size and business growth in China: The role of comprehensive social competency. Entrepreneurship \& Regional Development 22(7/8): 675-705.

Zizah, C. S., Ridzuan, M. S., Scott-Ladd, B., and Entrekin, L. (2007). SMEs Internalization: Discussing on how networking helps SMEs to go International. Proceeding of $4^{\text {th }}$ SMEs in a Global Economy International Conference. Shah Alam: UPENA. 